\title{
Article
}

Mycosphere

\section{Diaporthe juglandicola sp. nov. (Diaporthales, Ascomycetes), evidenced by morphological characters and phylogenetic analysis}

\section{Yang Q, Fan XL, Du Z and Tian CM*}

The Key Laboratory for Silviculture and Conservation of Ministry of Education, Beijing Forestry University, Beijing 100083, China

Yang Q, Fan XL, Du Z, Tian CM 2017 - Diaporthe juglandicola sp. nov. (Diaporthales, Ascomycetes), evidenced by morphological characters and phylogenetic analysis. Mycosphere 8(5), 817-826, Doi 10.5943/mycosphere/8/5/3

\begin{abstract}
Diaporthe juglandicola sp. nov, collected from diseased branches of Juglans mandshurica in Beijing, China, is described and illustrated in this paper. Evidence for this new species is provided by its holomorphic morphology and phylogenetic analysis. Morphologically, the asexual morph produces hyaline, aseptate, ellipsoidal, alpha conidia $(8.1-8.7 \times 2.3-2.9 \mu \mathrm{m})$, while the sexual morph produces 8-spored, unitunicate, clavate to cylindric asci and fusoid, 0-1-septate ascospores. The phylogeny inferred from combined multi-locus sequences (CAL, HIS, ITS, TEF1- $\alpha$, TUB) grouped the isolates of the new species into a distinct lineage.
\end{abstract}

Key words - dieback - molecular phylogeny - new species - taxonomy

\section{Introduction}

The genus Diaporthe (syn. Phomopsis) was established by Nitschke (1870). Species of Diaporthe occur widely in natural ecosystems, comprising endophytes and saprobes, as well as plant pathogens (Uecker 1988, Rehner \& Uecker 1994, Rossman \& Palm-Hernández 2008, Udayanga et al. 2011, 2012a, b). According to Index Fungorum, there are 977 names in Diaporthe and 980 names in Phomopsis, although the relationships between the asexual and sexual taxa are mostly unclear. The current International Code of Nomenclature for algae, fungi, and plants (ICN) requires a single-name for pleomorphic fungi (McNeill et al. 2012). Diaporthe (1870) is older than the asexual morph name Phomopsis (1905) and is recommended for use (Rossman et al. 2015).

Species in Diaporthe were originally identified based on host association and morphological characters (van der Aa et al. 1990). However, the utility of morphology has generally been shown to be of little use for species identification as there is considerable plasticity of the characters within a species (Rehner \& Uecker 1994, Mostert et al. 2001, Santos \& Phillips 2009, Santos et al. 2010, Udayanga et al. 2011, 2012a). Host association has also been shown to bear little significance when referring to phylogenetic relationships (Brayford 1990, Rehner \& Uecker 1994, Mostert et al. 2001, Santos \& Phillips 2009, Udayanga et al. 2011, 2012a, b, 2014b, 2015). More than one species of Diaporthe can often be recovered from a single host, while one species can be associated with many different hosts (Santos \& Phillips 2009, Diogo et al. 2010, Santos et al. 2011, Gomes et al. 2013). Multi-locus phylogenetic analyses have become the most effective tool for taxonomic studies to identify cryptic fungal species in Diaporthe (Cai et al. 2011a, b, Udayanga et al. 2012a, b, Gomes et al. 2013, Huang et al. 2013, 2015, Udayanga et al. 2014a, b, 2015, Fan et al. 2015, Du et 
al. 2016, Gao et al. 2016).

In China, several Diaporthe species have been characterized and illustrated based on morphological characteristics and multi-locus phylogeny (Huang et al. 2013, 2015, Gao et al. 2014, 2015, 2016, Fan et al. 2015, Du et al. 2016). During investigations of forest pathogens in Beijing, fresh specimens from symptomatic branches of Juglans mandshurica were collected. From these, one additional Diaporthe species is newly described and characterized based on morphological characters and multi-locus phylogeny (CAL, HIS, ITS, TEF1- $\alpha$, TUB). Both morphology and sequence data confirmed that the new collection represents a new species in Diaporthe following the guidelines for new species in Jeewon \& Hyde (2016).

\section{Materials \& Methods}

\section{Isolation}

Fresh collections of Diaporthe were made from infected branches of Juglans mandshurica collected in Beijing, China. Strains were isolated from fresh diseased branches and grown from single ascospores or conidia plated on potato dextrose agar (PDA) following method by Chomnunti et al. (2014). After incubation at $25^{\circ} \mathrm{C}$ for up to $24 \mathrm{~h}$, single germinating conidia were removed and plated onto fresh PDA plates. Two strains (one from the asexual morphs and the other from the sexual morphs) were used in the phylogenetic analysis (Table 1). Specimens and isolates of the new species are deposited in the Museum of Beijing Forestry University (BJFC). Axenic cultures are maintained in the China Forestry Culture Collection Center (CFCC).

\section{Morphology}

Morphological observations were based on features of the fruiting bodies produced on infected plant tissues and micromorphology, supplemented by cultural characteristics. Morphological characteristics of the fruiting bodies were recorded with a Leica stereomicroscope (M205 FA). Micromorphological observations were determined with a Leica compound microscope (DM 2500). More than 20 fruiting bodies were sectioned, both vertically and horizontally, and 50 spores were selected randomly for measurement. For observation of culture characteristics, two strains were selected for the species, and three cultures were replicated for each strain. All cultures incubated on PDA in the dark at $25^{\circ} \mathrm{C}$ were observed and recorded. This included colony colour, texture and arrangement of the conidiomata in culture, at 3, 7, and 30-days in darkness.

\section{DNA extraction, PCR amplification, and sequencing}

Genomic DNA was extracted from colonies grown on PDA overlain with cellophane using a modified CTAB method (Doyle \& Doyle 1990) and then estimated by electrophoresis in $1 \%$ agarose gels, and the quality was measured by NanoDrop ${ }^{\mathrm{TM}} 2000$ (Thermo, USA) following the user manual (Desjardins et al. 2009). PCR amplifications were performed in DNA Engine (PTC-200) Peltier Thermal Cycler (Bio-Rad Laboratories, CA, USA). The ITS region was amplified using primers ITS1 and ITS4 (White et al. 1990). The CAL region was amplified using primers CAL-228F and CAL-737R (Carbone \& Kohn 1999). The HIS region was amplified using primers CYLH4F (Crous et al. 2004a) and H3-1b (Glass \& Donaldson 1995). The partial translation elongation factor 1-alpha (TEF1- $\alpha$ ) gene region was amplified using primers EF1-728F and EF1-986R (Carbone \& Kohn 1999) and TUB was amplified using primers Bt2a and Bt2b (Glass \& Donaldson 1995). The PCR amplification products were estimated visually by electrophoresis in 2\% agarose gels. DNA sequencing was performed using an ABI PRISM ${ }^{\circledR}$ 3730XL DNA Analyzer with BigDye ${ }^{\circledR}$ Terminater Kit v.3.1 (Invitrogen) at the Shanghai Invitrogen Biological Technology Company Limited (Beijing, China).

\section{DNA sequence analysis}

Sequences from this study, along with reference sequences from GenBank (Table 1) were 
aligned with MAFFT v.6 (Katoh \& Toh 2010) and edited manually with MEGA6 (Tamura et al. 2013). Phylogenetic analysis was carried out with PAUP v.4.0b10 for maximum parsimony (MP) analysis (Swofford 2003), MrBayes v.3.1.2 for Bayesian analysis (Ronquist \& Huelsenbeck 2003), and PhyML v.7.2.8 for maximum likelihood (ML) analysis (Guindon et al. 2010). The analyses were performed on the combined multi-gene dataset (CAL, HIS, ITS, TEF1- $\alpha$, TUB) to compare Diaporthe species from other ex-type reference in recent studies (Udayanga et al. 2011, 2012a, b, 2014a, b, 2015, Gomes et al. 2013, Gao et al. 2014, 2015, Fan et al. 2015). Diaporthella corylina (CBS 121124) was selected as outgroup in this analysis (Gomes et al. 2013). Trees were visualised with FigTree v.1.3.1 (Rambaut \& Drummond 2010).

Table 1 Isolates and GenBank accession numbers used in this study.

\begin{tabular}{|c|c|c|c|c|c|c|}
\hline \multirow{2}{*}{ Species } & \multirow{2}{*}{ Isolates } & \multicolumn{5}{|c|}{ GenBank accession numbers } \\
\hline & & ITS & CAL & HIS & TEF1- $\alpha$ & TUB \\
\hline D. alleghaniensis ${ }^{\mathrm{T}}$ & CBS 495.72 & KC343007 & KC343249 & KC343491 & KC343733 & KC343975 \\
\hline D. alnea $^{\mathrm{T}}$ & CBS 146.46 & KC343008 & KC343250 & KC343492 & KC343734 & KC343976 \\
\hline D. ampelina ${ }^{\mathrm{T}}$ & STE-U 2660 & AF230751 & AY745026 & - & AY745056 & JX275452 \\
\hline D. amygdali ${ }^{\mathrm{T}}$ & CBS 126679 & KC343022 & KC343264 & KC343506 & KC343748 & KC343990 \\
\hline D. angelicae ${ }^{\mathrm{T}}$ & CBS 111592 & KC343027 & KC343269 & KC343511 & KC343753 & KC343995 \\
\hline D. apiculatum $^{\mathrm{T}}$ & LC3418 & KP267896 & - & - & KP267970 & KP293476 \\
\hline D. $\operatorname{arecae}^{\mathrm{T}}$ & CBS 161.64 & KC343032 & KC343274 & KC343516 & KC343758 & KC344000 \\
\hline D. arengae $^{\mathrm{T}}$ & CBS 114979 & KC343034 & KC343276 & KC343518 & KC343760 & KC344002 \\
\hline D. aspalathi ${ }^{\mathrm{T}}$ & CBS 117169 & KC343036 & KC343278 & KC343520 & KC343762 & KC344004 \\
\hline D. australafricana ${ }^{\mathrm{T}}$ & CBS 111886 & KC343038 & KC343280 & KC343522 & KC343764 & KC344006 \\
\hline D. biconispora ${ }^{\mathrm{T}}$ & ICMP20654 & KJ490597 & - & KJ490539 & KJ490476 & KJ490418 \\
\hline D. bicincta $^{\mathrm{T}}$ & CBS 121004 & KC343134 & KC343376 & KC343618 & KC343860 & KC344102 \\
\hline D. biguttulata ${ }^{\mathrm{T}}$ & ICMP20657 & KJ490582 & - & KJ490524 & KJ490461 & KJ490403 \\
\hline D. biguttusis ${ }^{\mathrm{T}}$ & CGMCC 3.17081 & KF576282 & - & - & KF576257 & KF576306 \\
\hline D. castaneae-mollisimae ${ }^{\mathrm{T}}$ & DNP 128 & JF957786 & JX197430 & - & JX275401 & JX275438 \\
\hline D. celastrina & CBS 139.27 & KC343047 & KC343289 & KC343531 & KC343773 & KC344015 \\
\hline D. citri $^{\mathrm{T}}$ & CBS 135422 & KC843311 & KC843157 & - & KC843071 & KC843187 \\
\hline D. citrichinensis $^{\mathrm{T}}$ & ZJUD34 & JQ954648 & KC357494 & - & JQ954666 & - \\
\hline D. cotoneastri ${ }^{\mathrm{T}}$ & CBS 439.82 & KC343090 & KC343332 & KC343574 & KC343816 & KC344058 \\
\hline D. crotalariae $^{\mathrm{T}}$ & CBS 162.33 & KC343056 & KC343298 & KC343540 & KC343782 & KC344024 \\
\hline D. discoidispora ${ }^{\mathrm{T}}$ & ICMP20662 & KJ490624 & - & KJ490566 & KJ490503 & KJ490445 \\
\hline D. eres $^{\mathrm{T}}$ & AR5193 & KJ210529 & KJ434999 & KJ420850 & KJ210550 & KJ420799 \\
\hline D. eugeniae & CBS 444.82 & KC343098 & KC343340 & KC343582 & KC343824 & KC344066 \\
\hline D. fraxini-angustifoliae ${ }^{\mathrm{T}}$ & BRIP 54781 & JX862528 & - & - & JX862534 & KF170920 \\
\hline D. fusicola ${ }^{\mathrm{T}}$ & CGMCC 3.17087 & KF576281 & KF576233 & - & KF576256 & KF576305 \\
\hline D. gardeniae & CBS 288.56 & KC343113 & KC343355 & KC343597 & KC343839 & KC344081 \\
\hline D. gulyae & BRIP 54025 & JF431299 & JN645803 & - & - & - \\
\hline D. helicis ${ }^{\mathrm{T}}$ & AR5211 & KJ210538 & KJ435043 & KJ420875 & KJ210559 & KJ420828 \\
\hline D. hickoriae ${ }^{\mathrm{T}}$ & CBS 145.26 & KC343118 & KC343360 & KC343602 & KC343844 & KC344086 \\
\hline D. hongkongensis ${ }^{\mathrm{T}}$ & CBS 115448 & KC343119 & KC343361 & KC343603 & KC343845 & KC344087 \\
\hline D. infecunda ${ }^{\mathrm{T}}$ & CBS 133812 & KC343126 & KC343368 & KC343610 & KC343852 & KC344094 \\
\hline D. juglandicola ${ }^{\mathrm{T}}$ & CFCC 51134 & KU985101 & KX024616 & KX024622 & KX024628 & KX024634 \\
\hline D. juglandicola & CFCC 51135 & KU985102 & KX024617 & KX024623 & KX024629 & KX024635 \\
\hline D. litchicola ${ }^{\mathrm{T}}$ & BRIP 54900 & JX862533 & - & - & JX862539 & KF170925 \\
\hline D. longicicola ${ }^{\mathrm{T}}$ & CGMCC 3.17089 & KF576267 & - & - & KF576242 & KF576291 \\
\hline D. lusitanicae ${ }^{\mathrm{T}}$ & CBS 123212 & KC343136 & KC343378 & KC343620 & KC343862 & KC344104 \\
\hline D. mahothocarpus ${ }^{\mathrm{T}}$ & CGMCC 3.15181 & KC153096 & - & - & KC153087 & KF576312 \\
\hline D. melonis $^{\mathrm{T}}$ & CBS 507.78 & KC343142 & KC343384 & KC343626 & KC343868 & KC344110 \\
\hline D. multigutullata ${ }^{\mathrm{T}}$ & ICMP20656 & KJ490633 & - & KJ490575 & KJ490512 & KJ490454 \\
\hline D. musigena ${ }^{\mathrm{T}}$ & CBS 129519 & KC343143 & KC343385 & KC343627 & KC343869 & KC344111 \\
\hline D. neilliae $^{\mathrm{T}}$ & CBS 144.27 & KC343144 & KC343386 & KC343628 & KC343870 & KC344112 \\
\hline D. neoarctii ${ }^{\mathrm{T}}$ & CBS 109490 & KC343145 & KC343387 & KC343629 & KC343871 & KC344113 \\
\hline
\end{tabular}




\begin{tabular}{|c|c|c|c|c|c|c|}
\hline D. nobilis & CBS 113470 & КС343146 & КС343388 & КС343630 & KC343872 & КС344114 \\
\hline D. nотигаi & CBS 157.29 & КC343154 & KC343396 & КC343638 & KC343880 & KC344122 \\
\hline D. nothofagi $^{\mathrm{T}}$ & BRIP 54801 & JX862530 & - & - & JX862536 & KF170922 \\
\hline D. novem $^{\mathrm{T}}$ & CBS 127270 & KC343156 & KC343398 & KC343640 & KC343882 & KC344124 \\
\hline D. oracciniii $^{\mathrm{T}}$ & LC3166 & KP267863 & - & KP293517 & KP267937 & KP293443 \\
\hline D. ovalispora ${ }^{\mathrm{T}}$ & ICMP20659 & KJ490628 & - & KJ490570 & KJ490507 & KJ490449 \\
\hline D. ovoicicola ${ }^{\mathrm{T}}$ & CGMCC 3.17092 & KF576264 & KF576222 & - & KF576239 & KF576288 \\
\hline D. pascoei ${ }^{\mathrm{T}}$ & BRIP 54847 & JX862532 & - & - & JX862538 & KF170924 \\
\hline D. penetriteum ${ }^{\mathrm{T}}$ & LC3353 & KP714505 & - & KP714493 & KP714517 & KP714529 \\
\hline D. pseudomangiferae ${ }^{\mathrm{T}}$ & CBS 101339 & KC343181 & КC343423 & КC343665 & КC343907 & КС344149 \\
\hline D. pseudophoenicicola & CBS 462.69 & KC343184 & KC343426 & КС343668 & KC343910 & КС344152 \\
\hline D. pterocarpicola ${ }^{\mathrm{T}}$ & MFLUCC 100580 & JQ619887 & JX197433 & - & JX275403 & JX275441 \\
\hline D. pulla ${ }^{\mathrm{T}}$ & CBS 338.89 & KC343152 & KC343394 & KC343636 & KC343878 & KC344120 \\
\hline D. rostrata ${ }^{\mathrm{T}}$ & CFCC 50062 & KP208847 & KP208849 & KP208851 & KP208853 & KP208855 \\
\hline D. rostrata & CFCC 50063 & KP208848 & KP208850 & KP208852 & KP208854 & KP208856 \\
\hline D. rudis $^{\mathrm{T}}$ & AR3422 & KC843331 & KC843146 & - & КС843090 & KC843177 \\
\hline D. schini $^{\mathrm{T}}$ & CBS 133181 & KC343191 & KC343433 & KC343675 & KC343917 & KC344159 \\
\hline D. subclavata ${ }^{\mathrm{T}}$ & ICMP20663 & KJ490587 & - & KJ490529 & KJ490466 & KJ490408 \\
\hline D. terebinthifolii ${ }^{\mathrm{T}}$ & CBS 133180 & KC343216 & KC343458 & KC343700 & KC343942 & KC344184 \\
\hline D. unshiuensis ${ }^{\mathrm{T}}$ & CGMCC 3.17569 & KJ490587 & - & KJ490529 & KJ490466 & KJ490408 \\
\hline D. vaccinii $^{\mathrm{T}}$ & CBS 160.32 & KC343228 & KC 343470 & KC343712 & КC343954 & КC344196 \\
\hline D. virgiliae $^{\mathrm{T}}$ & CMW 40755 & KP247573 & - & - & - & KP247582 \\
\hline D. viticola ${ }^{\mathrm{T}}$ & CBS 113201 & KC343234 & KC343476 & KC343718 & KC343960 & KC344202 \\
\hline D. woodii & CBS 558.93 & КС343244 & KC343486 & КС343728 & КС343970 & КС344212 \\
\hline Diaporthella corylina & CBS 121124 & KC343004 & КC343246 & КC343488 & KC343730 & КC343972 \\
\hline
\end{tabular}

${ }^{\mathrm{T}}$ Ex-type/Ex-epitype isolates. New species is bold.

For MP analyses, trees were inferred using the heuristic search option, TBR branch swapping and 1000 random sequence additions. Maxtrees were set to 5000, branches of zero length were collapsed and all equally parsimonious trees were saved. Clade stability was assessed with a bootstrap analysis of 1000 replicates (Hillis \& Bull 1993). Other calculated parsimony scores were tree length (TL), consistency index (CI), retention index (RI) and rescaled consistency (RC). ML analysis was performed with a GTR site substitution model (Guindon et al. 2010). Branch support was evaluated by a bootstrapping (BS) method with 1000 replicates (Hillis \& Bull 1993).

MrModeltest v. 2.3 was used to estimate the best nucleotide substitution model settings for each gene $((\operatorname{TrN}+\mathrm{I}+\mathrm{G})$ for ITS; $(\mathrm{HKY}+\mathrm{I}+\mathrm{G})$ for CAL and TEF1- $\alpha$; $(\mathrm{GTR}+\mathrm{I}+\mathrm{G})$ for HIS) (Posada \& Crandall 1998). The best fit model (GTR + I + G) was selected for CAL, HIS, ITS, TEF1- $\alpha$ and TUB sequence datasets. Bayesian inference (BI) analysis employing a Markov Chain Monte Carlo (MCMC) algorithum was performed to confirm the topology of the tree (Rannala \& Yang 1996). Suitable nucleotide substitution models were determined using MrModeltest v.2.3 (Posada \& Crandall 1998). Sequences data were deposited in GenBank (Table 1). The multilocus file was deposited inTreeBASE (www.treebase.org) as accession S20403. The taxonomic novelty was deposited in MycoBank (Crous et al. 2004b).

\section{Results \\ Phylogeny}

A total of 67 combined CAL, HIS, ITS, TEF1- $\alpha$, TUB sequences (including one outgroup) were aligned, comprising 2854 characters after alignment. Of these, 1342 characters were constant, 368 variable characters were parsimony-uninformative and 1144 characters were parsimony informative. The MP analysis resulted in 4 equally parsimonious trees and the first tree (TL $=5645$, $\mathrm{CI}=0.461, \mathrm{RI}=0.727, \mathrm{RC}=0.335$ ) is shown in Fig. 1 . The phylogenetic tree obtained from ML and BI with the MCMC algorithm was consistent with the MP tree. The branches with significant Bayesian posterior probability $(\geq 0.90)$ in $\mathrm{BI}$ are thickened in the phylogenetic tree. Isolates in the current study clustered in a distinct clade with high support (MP/ML/BI=100/100/1). It is 
recognized as a novel species and this is supported by morphological traits.

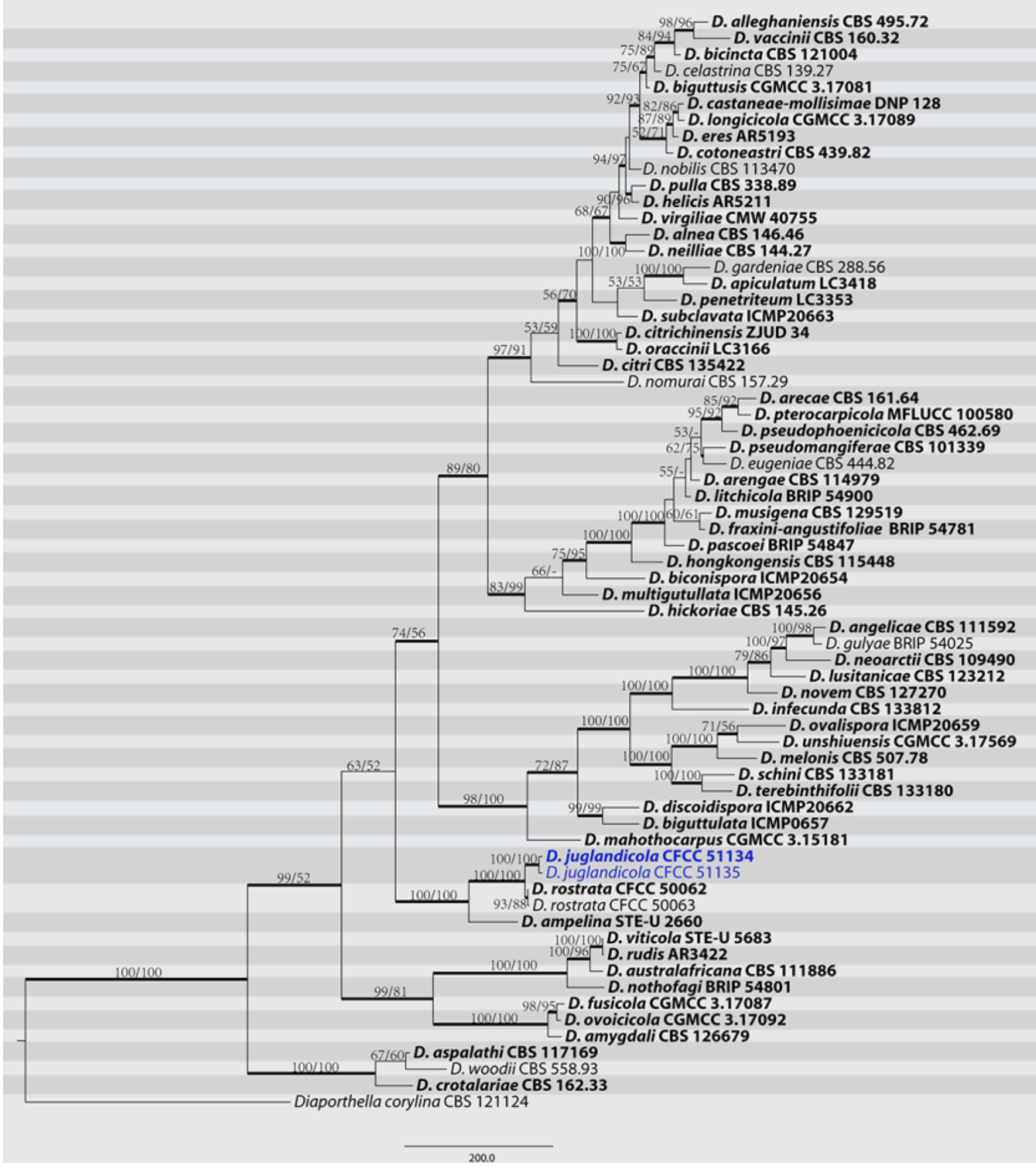

Figure 1 - Phylogram of CAL, HIS, ITS, TEF1- $\alpha$ and TUB regions based on MP, ML and Bayesian analysis. Values above the branches indicate maximum parsimony bootstrap (MP BP $\geq$ $50 \%$ ) and maximum likelihood bootstrap (ML BP $\geq 50 \%$ ). Thickened branches represent posterior probabilities (BI PP $\geq 0.90$ ) from Bayesian inference. Scale bar $=200$ nucleotide substitutions. The new sequences resulting from the current study are in blue. Ex-type strains are in bold.

\section{Taxonomy}

Diaporthe juglandicola C.M. Tian \& Q. Yang, sp. nov.

Index Fungorum number: 552939; Faces of fungi number: FoF03111

Etymology - juglandicola (Lat.): named after the host genus, Juglans.

Holotype - BJFC-S1342. 
Host/Distribution - from branches of Juglans mandshurica in China.
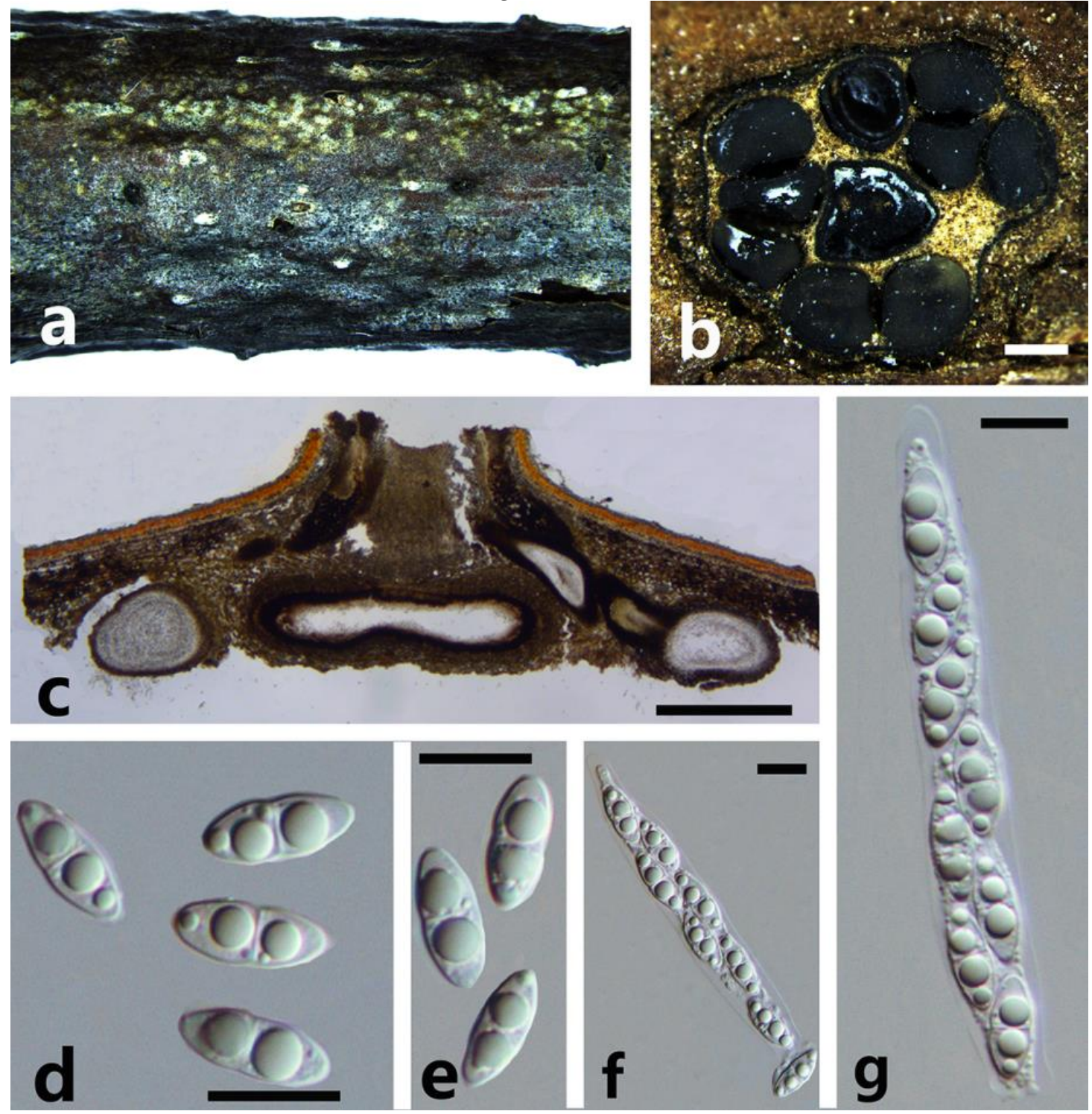

Figure 2 - The sexual morph of Diaporthe juglandicola from Juglans mandshurica (BJFC-S1342). a Habit of ascostroma on a twig. b Transverse sections through ascostroma. c Longitudinal sections through ascostroma. d-e Ascospores. f Asci with ascospores. g Asci. Scale bars: $b-c=500 \mu \mathrm{m}, \mathrm{d}-\mathrm{g}$ $=10 \mu \mathrm{m}$.

Pathogens on branches and twigs of Juglans mandshurica. Sexual morph: Ascostromata (1300-)1550-2200(-2350) $\mu \mathrm{m}(\mathrm{av} .=2000 \mu \mathrm{m}, \mathrm{n}=20)$ diameter, immersed in bark, erumpent, with 5-10 perithecia in black entostromata, extending to a large circular area with a black conceptacle, sometimes with central conidiomatal stromata surrounded by perithecium. Perithecia $(350-) 545-775(-850) \mu \mathrm{m}(\mathrm{av} .=700 \mu \mathrm{m}, \mathrm{n}=20)$ diameter, black, scattered, arranged circularly, ovoid to spherical. Asci $(68-) 70-79(-82.5) \times(7-) 7.5-9.5(-10.5) \mu \mathrm{m}(\mathrm{av} .=73 \times 8.5 \mu \mathrm{m}, \mathrm{n}=20)$ diameter, 8-spored, unitunicate, clavate to cylindric, sessile. Ascospores (8.5-)10-13.5(-15) $\times$ (3-)3.5-5.5(-6) $\mu \mathrm{m}(\mathrm{av} .=12 \times 5 \mu \mathrm{m}, \mathrm{n}=50)$ diameter, biseriate to partially biseriate in the ascus, fusoid, hyaline, 0-1-septate, 2-4-guttulate, smooth-walled. Asexual morph: Conidiomatal stromata immersed, erumpent through the bark surface, separate, globose, with a single locule. Ectostromatic disc black, with one ostiole per disc, $(300-) 445-550(-600) \mu \mathrm{m}(\mathrm{av} .=500 \mu \mathrm{m}, \mathrm{n}=20)$ diam. Locule undivided, (600-)650-780(-900) $\mu \mathrm{m}(\mathrm{av} .=750 \mu \mathrm{m}, \mathrm{n}=20)$ diam. Conidiophores reduced to conidiogenous cells. Conidiogenous cells $(13.5-) 15.5-18(-20) \times 1-1.2 \mu \mathrm{m}(\mathrm{av} .=16 \times 1$ $\mu \mathrm{m}, \mathrm{n}=50)$ diam, hyaline, branched, phialides, cylindrical, straight or slightly curved. Alpha conidia $(7.5-) 8-9(-9.5) \times 2.5-3.0(-3.2) \mu \mathrm{m}(\mathrm{av} .=8.5 \times 2.7 \mu \mathrm{m}, \mathrm{n}=50)$ diameter, hyaline, aseptate, 
smooth, abundant in culture and on twigs, ellipsoidal, biguttulate. Beta conidia not present.
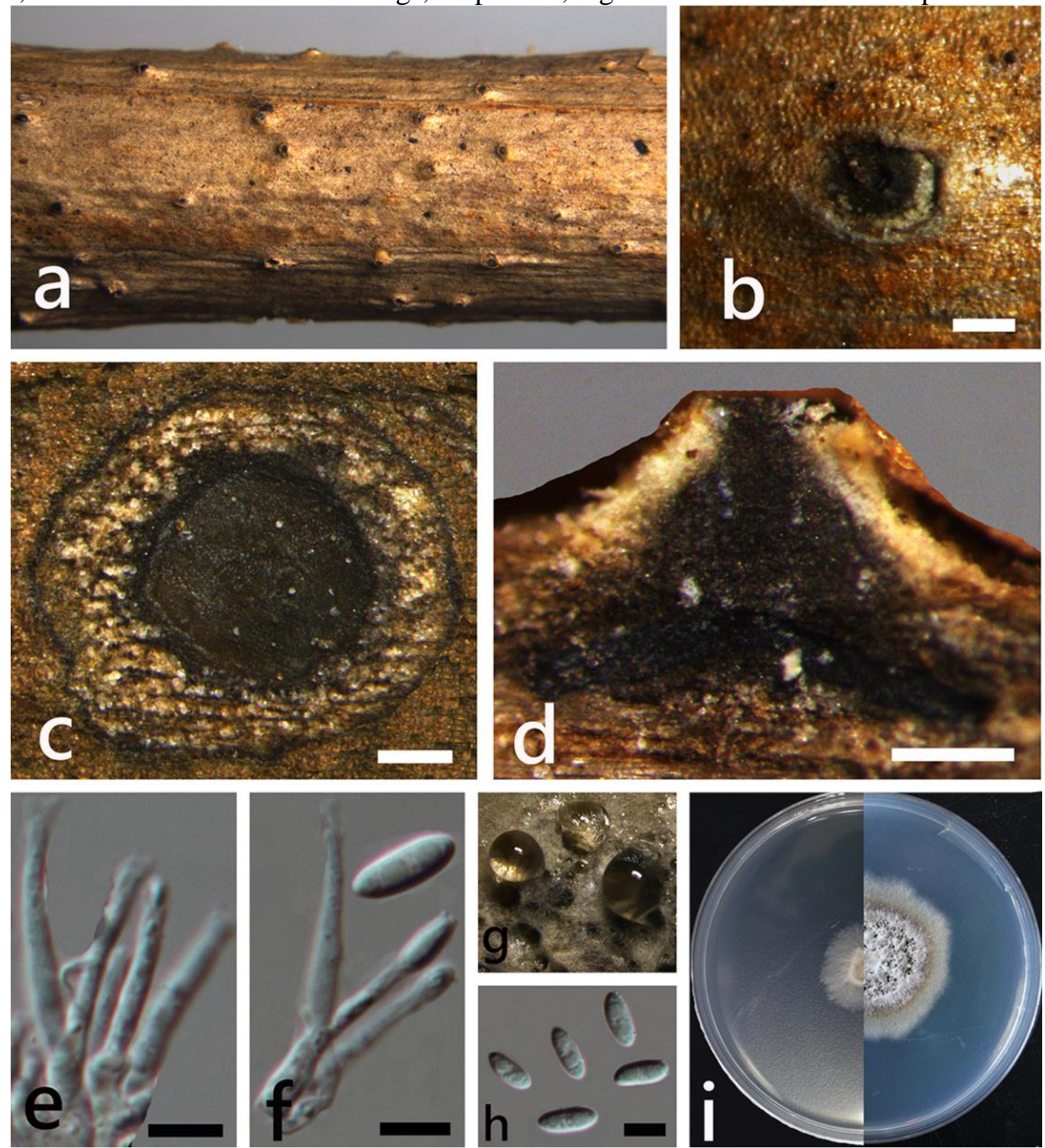

Figure 3 - The asexual morph of Diaporthe juglandicola from Juglans mandshurica (BJFC-S1341). a-b Habit of conidiomata on a twig. c Transverse sections through conidiomata. d Longitudinal sections through conidiomata. e-f Conidiophores. $\mathbf{g}$ conidiomata in culture. $\mathbf{h}$ alpha conidia. i Colonies on PDA at 3 days (left) and 30 days (right). Scale bars: $b-d=200 \mu \mathrm{m}, \mathrm{e}-\mathrm{f}, \mathrm{h}=5$ $\mu \mathrm{m}$.

Culture characters - Culture incubated on PDA at first white, becoming slightly brown. Aerial mycelium white, cottony, with irregular margin. Conidiomata distributed over agar surface.

Material examined - CHINA, Beijing City, Yanqing County, Songshan Nature Reserve, $40^{\circ} 30^{\prime} 26.30^{\prime \prime} \mathrm{N}, 115^{\circ} 47^{\prime} 44.45^{\prime \prime} \mathrm{E}, 810 \mathrm{~m}$ asl, on twigs and branches of Juglans mandshurica, coll. S.S. Hao, 9 May 2015 (BJFC-S1342, holotype), ex-type culture, CFCC 51134. Beijing City: Mentougou District, 39 57'35.21"N, 115'26'06.50"E, $1157 \mathrm{~m}$ asl, on twigs and branches of Juglans mandshurica, coll. Q. Yang, 17 August 2015 (BJFC-S1341, paratype), living culture, CFCC 51135.

Notes - This new species is introduced as molecular data showed it to be distinct, and this is also supported by morphological traits. The phylogram clustered in 67 clades with 57 ex-type Diaporthe strains distinguished the new species with high support (MP/ML/BI=100/100/1) (Fig. 1). Diaporthe juglandicola appears closely related to D. rostrata (identity in ITS: 464/464; in CAL: 482/485; in HIS: 441/451; in TEF1- $\alpha$ : 326/330; in TUB: 693/695). Morphologically, it is 
characterized by ellipsoidal, aseptate, biguttulate alpha conidia and unitunicate, clavate to cylindric asci. However, Diaporthe juglandicola can be distinguished by its bigger perithecia (545-775 vs. $280-370 \mu \mathrm{m})$ and smaller asci $(70-79 \times 7.5-9.5$ vs. $72-86 \times 10.5-13.5 \mu \mathrm{m})$, ascospores $(10-13.5 \times$ $3.5-5.5$ vs. $13-16.5 \times 5.5-6.5 \mu \mathrm{m})($ Fan et al. 2015$)$.

\section{Discussion}

In this study, Diaporthe juglandicola was found on twigs and branches of Juglans mandshurica in China with both sexual and asexual morphs. Two representative strains, one from an ascospore and one from a conidium, were used in the phylogenetic analysis. Two specimens, one with both sexual and asexual morphs, and the other with asexual morph only are deposited as the holotype and paratype. We describe and illustrate the holomorph of this species, the asexual morph occasionally occurred around or in the centre of the sexual perithecia (Fig. 3c). And it is clearly distinguished from D. rostrata, which also reported from Juglans mandshurica in China. Diaporthe juglandicola can be distinguished from $D$. rostrata by the smaller asci, ascospores and bigger perithecia. Besides, D. juglandicola has a small group of ascomata (5-10 vs. 13-32) and can be separated by the size of smaller alpha coidia $(8.0-9.0 \times 2.5-3.0$ vs. 8.5-11.5 $\times 4-5 \mu \mathrm{m})$ (Fan et al. 2015).

The morphological characteristics usually used for species delimitation in Diaporthe include cultural appearance, shape and size of conidiomata, conidiophores and alpha and beta conidia (Rehner \& Uecker 1994, Santos et al. 2011, Thompson et al. 2011, Udayanga et al. 2011, 2012a, b, 2014a, b, 2015, Gomes et al. 2013, Gao et al. 2014, 2015, 2016). However, species delimitation in Diaporthe based on morphological characters is challenging, as most taxa in culture do not produce all spore states of the asexual (alpha, beta and gamma conidia) or the sexual morph (Udayanga et al. 2014a, b, 2015). By means of molecular sequence data, much progress has been made towards identifying and characterizing in the genus Diaporthe (Gao et al. 2014, 2015, 2016, Udayanga et al. 2014a, b, 2015, Dissanayake et al. 2015, Fan et al. 2015, Du et al. 2016). Taylor et al. (2000) proposed the Genealogical Concordance Phylogenetic Species Recognition (GCPSR) concept to recognize the limits of fungi species, using the phylogenetic concordance of multiple unlinked genes. The adoption of genealogical concordance for species recognition in Diaporthe enabled us to distinguish species that were otherwise not possible to identify due to either sterility, or the lack or loss of specific character states (Udayanga et al. 2014a, b, 2015). In this study, phylogenetic analysis based on sequences of multiple loci (CAL, HIS, ITS, TEF1- $\alpha$ and TUB) demonstrated one distinctive new species in Diaporthe with highly supported clades and supported by the holomorphic morphology

\section{Acknowledgements}

This study is financed by National Natural Science Foundation of China (Project No.: 31670647) and supported by "Graduate Training and Development Program" of Beijing Municipal Commission of Education (BLCXY201625). We are grateful to Chungen Piao, Minwei Guo (China Forestry Culture Collection Center (CFCC), Chinese Academy of Forestry, Beijing) for support of strain preservation during this study.

\section{References}

Brayford D. 1990 - Variation in Phomopsis isolates from Ulmus species in the British Isles and Italy. Mycological Research 94, 691-697.

Cai L, Giraud T, Zhang N, Begerow D et al. 2011a - The evolution of species concepts and species recognition criteria in plant pathogenic fungi. Fungal Diversity 50, 121-133.

Cai L, Udayanga D, Manamgoda DS, Maharachchikumbura SSN et al. 2011b - The need to carry out re-inventory of plant pathogenic fungi. Tropical Plant Pathology 36, 205-213.

Carbone I, Kohn LM. 1999 - A method for designing primer sets for speciation studies in filamentous ascomycetes. Mycologia 91, 553-556. 
Chomnunti P, Hongsanan S, Aguirre-Hudson B, Tian Q et al. 2014 - The sooty moulds. Fungal Diversity 66, 1-36.

Crous PW, Gams W, Stalpers JA, Robert V, Stegehuis G. 2004a - MycoBank: an online initiative to launch mycology into the 21st century. Studies in Mycology 50, 19-22.

Crous PW, Groenewald JZ, Risède JM, Simoneau P, Hywel-Jones NL. 2004b - Calonectria species and their Cylindrocladium anamorphs: species with sphaeropedunculate vesicles. Studies in Mycology 50, 415-430.

Desjardins P, Hansen JB, Allen M. 2009 - Microvolume protein concentration determination using the NanoDrop 2000c spectrophotometer. Journal of Visualized Experiments 33, 1-3.

Diogo E, Santos JM, Phillips AJ. 2010 - Phylogeny, morphology and pathogenicity of Diaporthe and Phomopsis species on almond in Portugal. Fungal Diversity 44, 107-115.

Dissanayake AJ, Liu M, Zhang W, Chen Z et al. 2015 - Morphological and molecular characterisation of Diaporthe species associated with grapevine trunk disease in China. Fungal Biology 119, 283-294.

Doyle JJ, Doyle JL. 1990 - Isolation of plant DNA from fresh tissue. Focus 12, 13-15.

Du Z, Fan XL, Hyde KD, Yang Q et al. 2016 - Phylogeny and morphology reveal two new species of Diaporthe from Betula spp. in China. Phytotaxa 269, 90-102.

Fan XL, Hyde KD, Udayanga D, Wu XY, Tian CM. 2015 - Diaporthe rostrata, a novel ascomycete from Juglans mandshurica associated with walnut dieback. Mycological Progress 14, 1-8.

Gao YH, Liu F, Cai L. 2016 - Unravelling Diaporthe species associated with Camellia. Systematics and Biodiversity 14, 102-117.

Gao YH, Su YY, Sun W, Cai L. 2015 - Diaporthe species occurring on Lithocarpus glabra in China, with descriptions of five new species. Fungal Biology 115, 295-309.

Gao YH, Sun W, Su YY, Cai L. 2014 - Three new species of Phomopsis in Gutianshan Nature Reserve in China. Mycological Progress 13, 111-121.

Glass NL, Donaldson GC. 1995 - Development of primer sets designed for use with the PCR to amplify conserved genes from filamentous ascomycetes. Applied and Environmental Microbiology 61, 1323-1330.

Gomes RR, Glienke C, Videira SIR, Lombar L et al. 2013 - Diaporthe: a genus of endophytic, saprobic and plant pathogenic fungi. Persoonia 31, 1-41.

Guindon S, Dufayard JF, Lefort V, Anisimova M et al. 2010 - New algorithms and methods to estimate maximum-likelihood phylogenies: assessing the performance of PhyML 3.0. Systematic Biology 59, 307-321.

Hillis DM, Bull JJ. 1993 - An empirical test of bootstrapping as a method for assessing confidence in phylogenetic analysis. Systematic Biology 42, 182-192.

Huang F, Hou X, Dewdney MM, Fu Y et al. 2013 - Diaporthe species occurring on Citrus in China. Fungal Diversity 61, 237-250.

Huang F, Udayanga D, Wang X, Hou X et al. 2015 - Endophytic Diaporthe associated with Citrus: A phylogenetic reassessment with seven new species from China. Fungal Biology 119, 331-347.

Jeewon R, Hyde KD, 2016 - Establishing species boundaries and new taxa among fungi: recommendations to resolve taxonomic ambiguities. Mycosphere 7, 1669-1677.

Katoh K, Toh H. 2010 - Parallelization of the MAFFT multiple sequence alignment program. Bioinformatics 26, 1899-1900.

McNeill J, Barrie FR, Buck WR, Demoulin V et al. 2012 - International Code of Nomenclature for algae, fungi, and plants (Melbourne Code). Regnum Vegetabile 154, 208.

Mostert L, Crous PW, Kang JC, Phillips AJ. 2001 - Species of Phomopsis and a Libertella sp. occurring on grapevines with specific reference to South Africa: morphological, cultural, molecular and pathological characterization. Mycologia 93, 146-167.

Nitschke T. 1870 - Pyrenomycetes Germanici. Verlag von Eduard Trewendt, Breslau.

Posada D, Crandall KA. 1998 - Modeltest: testing the model of DNA substitution. Bioinformatics $14,817-818$. 
Rambaut A, Drummond A. 2010 - FigTree v.1.3.1. Institute of Evolutionary Biology, University of Edinburgh, Edinburgh, UK.

Rannala B, Yang Z. 1996 - Probability distribution of molecular evolutionary trees: a new method of phylogenetic inference. Journal of Molecular Evolution 43, 304-311.

Rehner SA, Uecker FA. 1994 - Nuclear ribosomal internal transcribed spacer phylogeny and host diversity in the coelomycete Phomopsis. Canadian Journal of Botany 72, 1666-1674.

Ronquist F, Huelsenbeck JP. 2003 - MrBayes 3: Bayesian phylogenetic inference under mixed models. Bioinformatics 19, 1572-1574.

Rossman AY, Adams GC, Cannon PF, Castlebury LA et al. 2015 - Recommendations of generic names in Diaporthales competing for protection or use. IMA Fungus 6, 145-154.

Rossman AY, Palm-Hernández ME. 2008 - Systematics of plant pathogenic fungi: why it matters. Plant Disease 92, 1376-1386.

Santos JM, Correia VG, Phillips AJ. 2010 - Primers for mating-type diagnosis in Diaporthe and Phomopsis: their use in teleomorph induction in vitro and biological species definition. Fungal Biology 114, 255-270.

Santos JM, Phillips AJL. 2009 - Resolving the complex of Diaporthe (Phomopsis) species occurring on Foeniculum vulgare in Portugal. Fungal Diversity 34, 111-125.

Santos JM, Vrandečić K, Ćosić J, Duvnjak T, Phillips AJL. 2011 - Resolving the Diaporthe species occurring on soybean in Croatia. Persoonia 27, 9-19.

Swofford DL. 2003 - PAUP*: Phylogenetic analysis using parsimony, Version 4.0b10. Sinauer Associates, Suderland.

Tamura K, Stecher G, Peterson D, Filipski A, Kumar S. 2013 - MEGA6: molecular evolutionary genetics analysis version 6.0. Molecular Biology and Evolution 30, 2725-2729.

Taylor JW, Jacobson DJ, Kroken S, Kasuga T et al. 2000 - Phylogenetic species recognition and species concepts in fungi. Fungal Genetics and Biology 31, 21-32.

Thompson SM, Tan YP, Young AJ, Neate SM et al. 2011 - Stem cankers on sunflower (Helianthus annuus) in Australia reveal a complex of pathogenic Diaporthe (Phomopsis) species. Persoonia 27, 80-89.

Udayanga D, Castlebury LA, Rossman AY, Chukeatirote E, Hyde KD. 2014a - Insights into the genus Diaporthe: phylogenetic species delimitation in the D. eres species complex. Fungal Diversity 67, 203-229.

Udayanga D, Castlebury LA, Rossman AY, Chukeatirote E, Hyde KD. 2015 - The Diaporthe sojae species complex: Phylogenetic re-assessment of pathogens associated with soybean, cucurbits and other field crops. Fungal Biology 119, 383-407.

Udayanga D, Castlebury LA, Rossman AY, Hyde KD. 2014b - Species limits in Diaporthe: molecular re-assessment of $D$. citri, $D$. cytosporella, $D$. foeniculina and $D$. rudis. Persoonia $32,83-101$.

Udayanga D, Liu X, Crous PW, McKenzie EH, Chukeatirote E, Hyde KD. 2012a - A multi-locus phylogenetic evaluation of Diaporthe (Phomopsis). Fungal Diversity 56, 157-171.

Udayanga D, Liu X, McKenzie EH, Chukeatirote E et al. 2011 - The genus Phomopsis: biology, applications, species concepts and names of common phytopathogens. Fungal Diversity 50, 189-225.

Udayanga D, Liu X, McKenzie EH, Chukeatirote E, Hyde KD. 2012b - Multi-locus phylogeny reveals three new species of Diaporthe from Thailand. Cryptogamie, Mycologie 33, 295-309.

Uecker FA. 1988 A world list of Phomopsis names with notes on nomenclature, morphology and biology. Mycologia Memoir 13, 1-231.

van der Aa HA, Noordeloos ME, Gruyter JD. 1990 - Species concepts in some larger genera of the Coelomycetes. Studies in Mycology 32, 3-19.

White TJ, Bruns T, Lee S, Taylor J. 1990 - Amplification and direct sequencing of fungal ribosomal RNA genes for phylogenetics. PCR Protocols: A Guide to Methods and Applications 18, $315-322$. 